\title{
Cord Compression by Extramedullary Hematopoiesis in Polycythemia Vera
}

\author{
Lisa Reale \\ Thomas Jefferson University, lisa.domingo@jefferson.edu \\ Steve Zrada \\ Thomas Jefferson University \\ Jose Martinez \\ Thomas Jefferson University, Jose.Martinez@jefferson.edu
}

Follow this and additional works at: https://jdc.jefferson.edu/tmf

Part of the Medical Cell Biology Commons

Let us know how access to this document benefits you

\section{Recommended Citation}

Reale, Lisa; Zrada, Steve; and Martinez, Jose (2003) "Cord Compression by Extramedullary Hematopoiesis in Polycythemia Vera," The Medicine Forum: Vol. 4 , Article 9.

DOI: https://doi.org/10.29046/TMF.004.1.010

Available at: https://jdc.jefferson.edu/tmf/vol4/iss1/9

This Article is brought to you for free and open access by the Jefferson Digital Commons. The Jefferson Digital Commons is a service of Thomas Jefferson University's Center for Teaching and Learning (CTL). The Commons is a showcase for Jefferson books and journals, peer-reviewed scholarly publications, unique historical collections from the University archives, and teaching tools. The Jefferson Digital Commons allows researchers and interested readers anywhere in the world to learn about and keep up to date with Jefferson scholarship. This article has been accepted for inclusion in The Medicine Forum by an authorized administrator of the Jefferson Digital Commons. For more information, please contact: JeffersonDigitalCommons@jefferson.edu. 


\section{Cord Compression by Extramedullary Hematopoiesis in Polycythemia Vera}

Lisa Reale, MD, Resident, Internal Medicine, 2000-2003, Steve Zrada, MD, Jose Martinez, MD

A 73-year-old male with polycythemia vera and a history of prostate cancer presents to an outside hospital complaining of back pain of two months duration. He denied fevers, chills, night sweats, weight loss, lower extremity weakness and decreased sensation. Other than chronic constipation and urinary hesitancy, his review of systems was unremarkable. A spinal x-ray revealed a T12 vertebral fracture and the patient was transferred to Thomas Jefferson University Hospital for further management.

His polycythemia vera was last treated with phlebotomy 1 year ago. The patient had been treated with hydroxyurea in the past, but it was discontinued secondary to thrombocytopenia. A splenectomy had been performed four months prior to admission for persistent thrombocytopenia. Bone marrow examination prior to admission revealed a hypercellular bone marrow with myeloid and megakaryocytic hyperplasia, and moderate increase in reticulin fibers. BCR/ABL translocation was negative by reverse transcriptase PCR.

Clinical examination revealed no spinal or paraspinal tenderness. Strength was intact except for mild decreased strength and sensation in the left lower extremity with absent deep tendon reflexes. Sphincter tone was preserved.

An MRI revealed an extensive epidural mass spanning the length of the thoracic epidural space and the paraspinal areas with spinal cord compression from T6T8 (Fig. 1A). A biopsy of this mass revealed megakaryocytes and maturing myeloid and erythroid precursors compatible with extramedullary hematopoiesis (Fig. 2). The patient underwent radiation therapy with a total dose of $1500 \mathrm{cGy}$. His symptoms rapidly improved, with complete resolution of his symptoms by the end of his treatment. A repeat MRI two months later showed marked improvement in the epidural mass (Fig. 1B).
Figure 1. (A) Extensive tissue abnormality seen throughout the thoracic spine, involving the spinal canal, with mixed signal characteristics on this T2-weighted image.

(B) Marked improvement of epidural mass two months later.

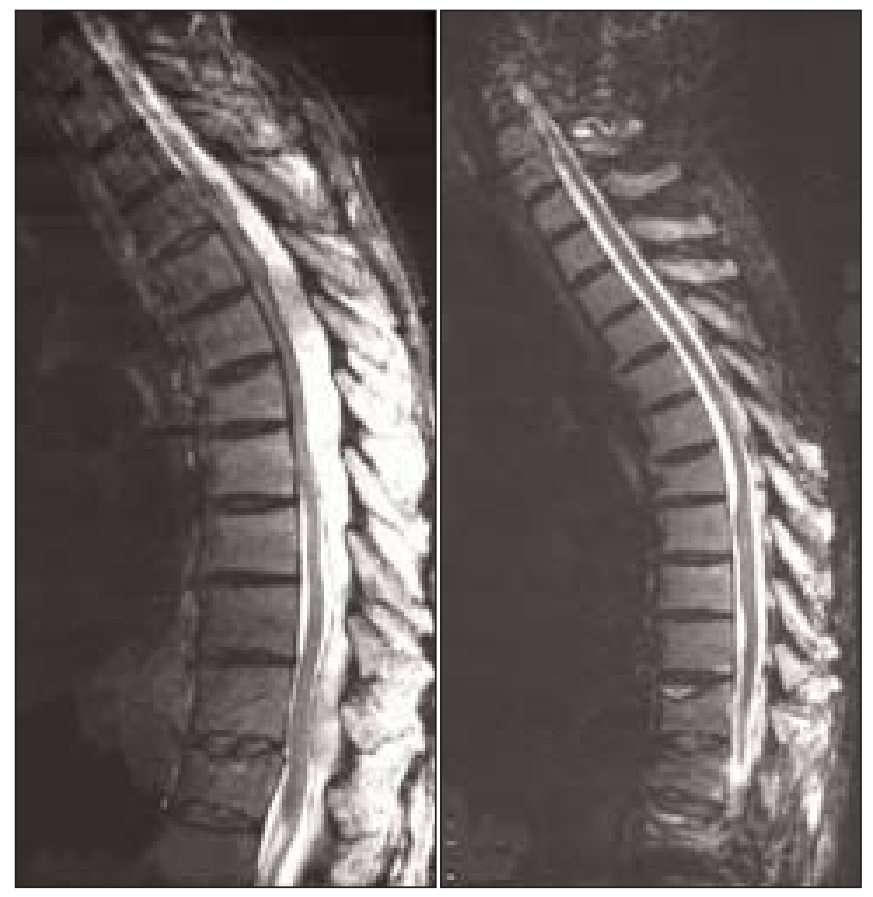

Figure 2. High power view of epidural mass biopsy, revealing megakaryocytes and maturing myeloid and erythroid precursors. 


\section{Discussion}

Extramedullary hematopoiesis (EMH) is a common finding in many chronic hematologic disorders, such as in hemoglobinopathies, lymphoma, leukemia and myeloproliferative disorders. The most common sites are the spleen and liver ${ }^{1}$. The adrenal glands, kidneys, pericardium ${ }^{2}$ and epidural space 1 are more unusual sites. The following table is a list of documented sites of extramedullary hematopoiesis in order of frequency ${ }^{1,3}$. Table 2 is a compilation of case reports of extramedullary hematopoiesis causing cord compression in myeloproliferative disorders, in particular myelofibrosis and polycythemia vera. The time from diagnosis of a myeloproliferative disorder ranged from newly diagnosed to twenty years. Of the seventeen cases found in the literature including this case report, only four of the eighteen cases presented with back pain ${ }^{4,5,6}$. In all of the cases that reported symptoms, the patients complained of neurologic deficits. The duration of symptoms ranged from two weeks to 1 year. The white count ranged from $1,600-100,200 / \mathrm{mL}$, hemoglobin ranged from $5.6-$ $20.1 \mathrm{~g} / \mathrm{dL}$ and platelets ranged from 8,000 $935,000 / \mathrm{mL}$. There was no correlation between blood counts and the severity of their symptoms nor the number of years from the diagnosis. The proliferative phase of polycythemia vera may portend a poorer prognosis ${ }^{8,9}$, however, there was no correlation between blood counts and severity of symptoms nor the number of years from diagnosis.

\section{Table 1. Sites of Documented Extramedullary Hematopoiesis}

\begin{tabular}{l}
\hline Spleen \\
\hline Liver \\
\hline Kidney \\
\hline Adrenal glands \\
\hline Lymph node \\
\hline Thymus \\
\hline Rungs and pleura \\
\hline Getroperitoneal adipose tissue \\
\hline Dura mater \\
\hline Broad ligament \\
\hline Breast \\
\hline Pweat glands of hands and feet \\
\hline Duratate and epididymis \\
\hline Thoracic duct
\end{tabular}

The location of the spinal cord compression in all except one case was in the mid-lower thoracic region. The lesions in the epidural space causing cord compression are most common in the mid-lower thoracic region. It is thought that this is because the spinal canal is narrower in this $\operatorname{area}^{10}$.

The pathophysiology of extramedullary hematopoiesis in the epidural space has not been fully elucidated; however, there are several theories. One suggests direct extension of bone marrow into the epidural space from the vertebral column or ribs through bone erosion or fracture. Alternatively, bone marrow elements may develop from primitive tissues resting along the spinal axis. Other theories include the escape of progenitor cells from the marrow with emboli to other organs, and new colony development from multipotent cells in the epidural space ${ }^{10}$.

Diagnosis of spinal cord compression due to EMH has been reported using conventional and CT myelography, CT and MRI. Because many of the cases in the literature were reported in the 1970s, eight of the seventeen cases were diagnosed by myelogram, three by CT and five by MRI. On CT, EMH appears as a homogenous, wellcircumscribed soft-tissue mass in the epidural area ${ }^{8,9}$. CT is able to accurately show the location and size of the mass as well as its relationship to other neighboring structures such as the spinal cord and vertebrae ${ }^{11}$. Myelography can demonstrate constriction of the subarachnoid space and compression of the spinal cord 9 . However, it is invasive and requires contrast administration. MRI, now the recommended test of choice ${ }^{12}$, is able to visualize cord compression and paraspinal masses without contrast administration. On T1 or T2 weighted spin echo, extramedullary hematopoiesis appears as a higher signal intensity compared to adjacent marrow of the vertebral bodies $^{13}$. MRI is also useful in differentiating EMH from other diagnoses, such as epidural abscess, neoplastic invasion and vertebral fracture from trauma ${ }^{14}$.

$\mathrm{EMH}$ is highly sensitive to ionizing radiation, requiring a dose of only $10-30 \mathrm{~Gy}^{15,16}$. Radiation therapy is now the current recommended treatment ${ }^{5}$. In the past, surgical excision followed by radiation had been recommended ${ }^{8,17,18}$. Surgery has the advantage of a definitive histologic diagnosis as well as immediate decompression. However, an invasive approach may be an unacceptable risk for the patient. Two of the published cases were treated with surgical excision and 
laminectomy without radiation. Neither patient improved with this modality. Seven patients were treated with combination surgery and XRT. Five of the seven having steady improvement. One of the two patients who did not respond, was pancytopenic at the time of diagnosis and the other had markedly elevated counts in all three cell lines compared to those who did respond. Eight patients were treated with radiation alone, with six having rapid clinical improvement. One of the two patients who did not respond was only given one dose of $1500 \mathrm{~Gy}$ and the other had a markedly elevated platelet count compared to those who did respond. The dosage of radiation ranged from 10 to $300 \mathrm{~Gy}$ with no difference in improvement with higher dosages. Blood transfusions have also been used in the treatment of $\mathrm{EMH}$, primarily with the hemoglobinopathies. The goal is to keep the hemoglobin level greater than $10 \mathrm{~g} / \mathrm{dL}$ to decrease the stimulus for further $\mathrm{EMH}^{19,20}$.

\begin{tabular}{|c|c|c|c|c|c|c|c|}
\hline Age/Sex & Diagnosis & Symptoms & $\begin{array}{l}\text { Symptom } \\
\text { Duration }\end{array}$ & Lab Values & $\begin{array}{l}\text { Radiologic } \\
\text { Findings }\end{array}$ & Treatment & Response \\
\hline 36 yo male & $\begin{array}{l}\text { Myelofibrosis } \\
(7 \mathrm{yrs})\end{array}$ & $\begin{array}{l}\text { Back pain, } \\
\text { B/L leg weakness } \\
\text { and Numbness }\end{array}$ & 2 weeks & $\begin{array}{l}\text { WBC normal } \\
\text { Hgb } 5.6 \\
\text { Plt } 8,000 \\
\end{array}$ & $\begin{array}{l}\text { Paravertebral } \\
\text { mass@ T2-11, } \\
\text { comp@ T5-8 (CT) }\end{array}$ & $\begin{array}{l}\text { 1600cGy over } 14 \\
\text { days with IV } \\
\text { dexamethasone }\end{array}$ & $\begin{array}{l}\text { Complete } \\
\text { clinical } \\
\text { recovery }\end{array}$ \\
\hline 61 yo male ${ }^{11}$ & $\begin{array}{l}\text { Myelofibrosis } \\
(10 \text { yrs })\end{array}$ & $\begin{array}{l}\text { Progressive } \\
\text { parapesis }\end{array}$ & 2 months & $\begin{array}{l}\text { WBC } 5.6 \\
\text { Hgb } 5.9\end{array}$ & $\begin{array}{l}\text { Paravertebral } \\
\text { mass @T8, comp } \\
@ \text { mid-thoracic level } \\
\text { (MRI) } \\
\end{array}$ & $\begin{array}{l}300 \text { Gy over } 10 \\
\text { fractions with IV } \\
\text { dexamethasone }\end{array}$ & $\begin{array}{l}\text { Complete } \\
\text { recovery over } \\
2 \text { wks }\end{array}$ \\
\hline 67 yo male & $\begin{array}{l}\text { Myelofibrosis } \\
(1.5 \text { yrs) }\end{array}$ & $\begin{array}{l}\text { Progressive } \mathrm{B} / \mathrm{L} \\
\text { lower limb } \\
\text { heaviness }\end{array}$ & 9 months & Plt 20,000 & $\begin{array}{l}\text { Extradural mass, } \\
\text { comp @ T6-7 } \\
\text { (MRI) } \\
\end{array}$ & $\begin{array}{l}\text { Partial laminectomy } \\
/ 2500 \text { cGY in } 5 \text { daily } \\
\text { doses over } 1 \text { week }\end{array}$ & $\begin{array}{l}\text { Steady } \\
\text { improvement }\end{array}$ \\
\hline 46 yo male & $\begin{array}{l}\text { Proliferative } \\
\text { phase of PV } \\
\text { (newly dx) }\end{array}$ & Paraplegia & 6 months & $\begin{array}{l}\text { WBC } 9.3 \\
\text { Hgb } 20 \\
\text { Plt } 240,000\end{array}$ & $\begin{array}{l}\text { Extradural mass } \\
\text { from T4-6 (CT) }\end{array}$ & $\begin{array}{l}\text { Laminectomy/ } \\
\text { phlebotomy } 3 \mathrm{x} / \text { week }\end{array}$ & $\begin{array}{l}\text { Died } 5 \text { month } \\
\text { later }\end{array}$ \\
\hline 70 yo male $\mathrm{m}^{17}$ & $\begin{array}{l}\text { PV (15 yrs) } \\
\text { Myelofibrosis } \\
(2 \text { yrs })\end{array}$ & Paraplegia & 4 months & $\begin{array}{l}\text { WBC } 64 \\
\text { Hgb } 12 \\
\text { Plt } 150,000\end{array}$ & $\begin{array}{l}\text { Complete block } \\
\text { @ T3-4 (myelogram) }\end{array}$ & $\begin{array}{l}\text { Surgical excision/ } \\
\text { Laminectomy }\end{array}$ & $\begin{array}{l}\text { Progressed to } \\
\text { AML, died }\end{array}$ \\
\hline 37 yo male ${ }^{21}$ & Myelofibrosis & - & - & - & $\begin{array}{l}\text { Paravertebral mass in } \\
\text { thoracic region, comp } \\
\text { from T3-5, L1-2 } \\
\text { (myelogram) }\end{array}$ & $2000 \mathrm{rads}$ & $\begin{array}{l}\text { Complete } \\
\text { recovery }\end{array}$ \\
\hline 36 yo male ${ }^{22}$ & $\begin{array}{l}\text { Myelofibrosis } \\
(6 \text { yrs })\end{array}$ & $\begin{array}{l}\text { Lower extremity } \\
\text { weakness }\end{array}$ & - & - & $\begin{array}{l}\text { Comp in upper thorac } \\
\text { /lumbar (myelogram) }\end{array}$ & $\begin{array}{l}\text { Radiation with IV } \\
\text { dexamethasone }\end{array}$ & $\begin{array}{l}\text { Rapid clinical } \\
\text { improvement }\end{array}$ \\
\hline 52 yo male & $\begin{array}{l}\text { Proliferative } \\
\text { phase of PV } \\
\text { (newly dx) }\end{array}$ & Quadriplegia & 5 months & $\begin{array}{l}\text { WBC } 17.5 \\
\text { Hgb 20.1 } \\
\text { Plt } 185,000 \\
\end{array}$ & $\begin{array}{l}\text { Extradural mass with } \\
\text { complete block@C5 } \\
\text { (CT) }\end{array}$ & $\begin{array}{l}\text { Single fraction } \\
\text { of } 1500 \mathrm{~Gy}\end{array}$ & $\begin{array}{l}\text { Died of } \\
\text { respiratory } \\
\text { failure } \\
\end{array}$ \\
\hline 74 yo female ${ }^{5}$ & $\begin{array}{l}\text { Myelofibrosis } \\
\text { (3 yrs) }\end{array}$ & $\begin{array}{l}\text { Low back pain, } \\
\text { leg numbness, } \\
\text { weakness }\end{array}$ & 6 months & $\begin{array}{l}\text { WBC } 4 \\
\text { Hgb 9.1 } \\
\text { Plt } 106,000\end{array}$ & $\begin{array}{l}\text { Paravertebral mass, } \\
\text { complete block @T4 } \\
\text { (myelogram) }\end{array}$ & $\begin{array}{l}\text { Laminectomy/3000 } \\
\text { rads in } 200 \text { rad } \\
\text { fractions over } 3 \text { week }\end{array}$ & $\begin{array}{l}\text { Complete relief } \\
\text { of back pain }\end{array}$ \\
\hline 68 yo male $\mathrm{m}^{23}$ & $\begin{array}{l}\text { Myelofibrosis } \\
(20 \text { yrs })\end{array}$ & $\begin{array}{l}\text { Leg stiffness, } \\
\text { weakness }\end{array}$ & 6 months & $\begin{array}{l}\text { WBC } 21.3 \\
\text { Hgb } 19.5 \\
\text { Plt } 450,000\end{array}$ & $\begin{array}{l}\text { Extradural mass from } \\
\text { T4-8 (myelogram) }\end{array}$ & $\begin{array}{l}\text { Laminectomy/900 rads } \\
\text { for } 3 \text { days/steroids }\end{array}$ & $\begin{array}{l}\text { No change } \\
@ 6 \text { months }\end{array}$ \\
\hline 50 yo male ${ }^{24}$ & $\begin{array}{l}\text { Myelofibrosis } \\
(20 \text { yrs })\end{array}$ & $\begin{array}{l}\text { Decreased sensation } \\
\text { in feet } b / l\end{array}$ & 1 year & Hgb 16.4 & $\begin{array}{l}\text { Extradural mass from } \\
\text { T3-12, block @T3 } \\
\text { (myelogram) }\end{array}$ & $\begin{array}{l}\text { Laminectomy } / 1000 \\
\text { rads in } 5 \text { doses over } \\
\text { seven days }\end{array}$ & $\begin{array}{l}\text { Symptoms free } \\
\text { @ } 6 \text { weeks }\end{array}$ \\
\hline 31 yo male & $\begin{array}{l}\text { Myelofibrosis } \\
\text { (6 yrs) }\end{array}$ & $\begin{array}{l}\text { Back pain, B/L } \\
\text { leg weakness }\end{array}$ & 1 year & - & T6 comp & Laminectomy/XRT & $\begin{array}{l}\text { Clinical } \\
\text { improvement }\end{array}$ \\
\hline 58 yo female ${ }^{25}$ & $\begin{array}{l}\text { Myelofibrosis } \\
\text { (newly dx) }\end{array}$ & $\begin{array}{l}\text { B/L leg stiffness, } \\
\text { numbness }\end{array}$ & 3 months & $\begin{array}{l}\text { WBC } 15.3 \\
\text { Hgb } 17.2 \\
\text { Plt 221,000 }\end{array}$ & $\begin{array}{l}\text { Compression@ T12 } \\
\text { (myelogram) }\end{array}$ & $\begin{array}{l}\text { Laminectomy/1000 } \\
\text { rads }\end{array}$ & $\begin{array}{l}\text { Clinical } \\
\text { Improvement }\end{array}$ \\
\hline 43 yo female ${ }^{26}$ & PV (15 yrs) & $\begin{array}{l}\text { B/L lower ext } \\
\text { numbness, weakness }\end{array}$ & - & $\begin{array}{l}\text { WBC } 52 \\
\text { Hgb } 39 \\
\text { Plt } 935,000 \\
\end{array}$ & $\begin{array}{l}\text { Epidural mass comp } \\
\text { @ T2-L3 (MRI) }\end{array}$ & $\mathrm{XRT} /$ steroids & Died \\
\hline 75 yo male & $\begin{array}{l}\text { Myelofibrosis } \\
\text { (newly dx) }\end{array}$ & Difficulty walking & 2 months & $\begin{array}{l}\text { WBC } 8.1 \\
\text { Hgb } 10.9 \\
\text { Plt 458,000 }\end{array}$ & Not done & No treatment & Died \\
\hline 60 yo male ${ }^{1}$ & $\begin{array}{l}\text { Myelofibrosis } \\
\text { (8 months) }\end{array}$ & $\begin{array}{l}\text { Sudden onset of } \\
\text { weakness/sphincter } \\
\text { dysfunction }\end{array}$ & - & $\begin{array}{l}\text { WBC } 9.8 \\
\text { Hgb } 4.5 \\
\text { Plt fl }\end{array}$ & $\begin{array}{l}\text { Extradural mass block } \\
\text { @ T8 (myelogram) }\end{array}$ & Laminectomy/XRT & Died soon after \\
\hline 68 yo male ${ }^{27}$ & $\begin{array}{l}\text { PV ( } 40 \text { yrs) } \\
\text { Myelofibrosis } \\
\text { (2 yrs) }\end{array}$ & B/L leg weakness & 4 weeks & Plt 9,000 & $\begin{array}{l}\text { Epidural mass, } \\
\text { comp @ T8-9 (MRI) }\end{array}$ & $\begin{array}{l}22 \mathrm{~Gy} \text { in } 4 \text { fractions, } \\
\text { Dexamethasone } 4 \mathrm{mg} \\
\text { QID }\end{array}$ & $\begin{array}{l}\text { Rapid } \\
\text { Improvement }\end{array}$ \\
\hline 56 yo male 28 & $\begin{array}{l}\text { Myelofibrosis } \\
\text { (8 months) }\end{array}$ & $\begin{array}{l}\text { Back pain, } \\
\text { weakness }\end{array}$ & 8 months & - & $\begin{array}{l}\text { Block from T4-11 } \\
\text { (myelogram) }\end{array}$ & $\begin{array}{l}\text { Laminectomy/2000 } \\
\text { rads }\end{array}$ & Unchanged \\
\hline 54 yo male ${ }^{29}$ & $\begin{array}{l}\text { Myelofibrosis } \\
\text { (3 yrs) }\end{array}$ & LE weakness & 3 years & - & $\begin{array}{l}\text { Block@L3 } \\
\text { (myelogram) }\end{array}$ & No treatment & $\begin{array}{l}\text { Died } 6 \text { months } \\
\text { later }\end{array}$ \\
\hline 73 yo male & PV & Back pain & 2 months & $\begin{array}{l}\text { WBC } 100.2 \\
\text { Hgb } 11.6 \\
\text { Plt } 68,000\end{array}$ & $\begin{array}{l}\text { Epidural mass, } \\
\text { compression @T6-8 } \\
\text { (MRI) }\end{array}$ & XRT & $\begin{array}{l}\text { Rapid clinical } \\
\text { improvement }\end{array}$ \\
\hline
\end{tabular}




\section{References}

1 Close AS, Taira Y, Cleveland DA. Spinal cord compression due to extramedullary haematopoiesis. Ann Intern Med 1958;48:421-7.

2 Imam T, Doll D. Acute Cardiac Tamponade Associated with Pericardial Extramedullary Hematopoiesis in Agnogenic Myeloid Metaplasia. Acta Haematol 1997;98:42-43.

3 Ligumski M, Polliack A, Benbassat J. Myeloid Metaplasia of the Central Nervous System in Patients with Myelofibrosis and Agnogenic Myeloid Metaplasia. Am J Med Sciences 1978;275:99-103.

4 Guermazi A, Miaux Y, Chiras J. Imaging of Spinal Cord Compression due to Thoracic Extramedullary Haematopoiesis in Myelofibrosis. Neuroradiology 1997;39:733-736.

5 Price F, Bell H. Spinal Cord Compression Due to Extramedullary Hematopoiesis. JAMA 1985;253:2876-2877.

6 Lowman RM, Bloor CM, Newcomb AW. Roentgen Manifestations of Thoracic Extramedullary Hematopoiesis. Dis Chest 1963;44:154-162.

7 Oliveira de Morais et al. Spinal Cord Compression due to Extramedullary Hematopoiesis in the Proliferative Phase of Polycythemia Vera. Acta Haematol 1996;96:242-244.

8 Jackson A, Burton IE. Retroperitoneal Mass and Spinal Cord Compresison due to Extramedullary Haemopoiesis in Polycythaemia Rubra Vera. Br J Radiol 1989;62:944-947.

9 Cook G, Sharp RA. Spinal Cord Compression due to Extramedullary Haemopoiesis in Myelofibrosis. J Clin Path 1994;47:464-465.

10 Heffner RR, Koehl RH. Hemopoiesis in the Spinal Epidural Space. J Neurosurg 1970;32:485-490.

11 De Klippel et al. Progressive Paraparesis due to Thoracic Extramedullary Hematopoiesis in Myelofibrosis. J Neurosurg 1993;79:125-127.

12 Ma SK, Chan JC, Wong KF. Diagnosis of Spinal Extramedullary Hemopoiesis by Magnetic Resonance Imaging. Am J Med 1993;95:111-112.

13 Papvasilou C et al. CT and MRI of Symptomatic Involement by Extramedullary Hematopoiesis. Clin Radiol 1990;42:91-92.

14 Lau CK, Chan CK, Chow YYN. Cord Compression Due to Extramedullary Hemopoiesis in a Patient with Thallasemia. Spine 1994;19:2467-2470
15 Jackson DV, Randall ME, Richards F. Spinal Cord Compression due to Extramedullary Hematopoiesis in Thalasemia. Surg Neurol 1988;29:389-392.

16 Papavasiliou C, Sandilos P. Effect of Radiotherapy on Symptoms due to Heterotopic Marrow in Betathalassemia. Lancet 1987;1:13-14.

17 Oustwani MB, Kurtides ES, Christ M, Ciric I. Spinal Cord Compression with Paraplegia in Myelofibrosis. Arch Neurol 1980;37:389-390.

18 Shin KH, Sharma S et al. Combined Radiotherapeutic and Surgical management of a Spinal Cord Compression by Extramedullary Hematopoiesis in a Patient with Hemoglobin E Beta-Thalasemia. Acta Haematol 1994;91:154-157.

19 Singounas EG et al. Paraplegia in a Pregnant Thalassemic Woman due to Extramedullary Hematopoiesis. Surg Neurol 1991;36:210-215.

20 Mann KS et al. Paraplegia due to Extramedullary Hematopoiesis in Thalassemia. J Neurosurg 1987;66:938-940.

21 Bree et al. Extramedullary Hematopoiesis in the Spinal Epidural Space. J Can Ass Radiol 1974;25:297-298.

22 Cromwell L, Kerber C. Spinal Cord Compression by Extramedullary Hematopoiesis in Agnogenic Myeloid Metaplasia. Radiol 1978;128:118.

23 Rice GP et al. Extramedulary Hematopoiesis and Spinal Cord Compression Complicating Polycythemia Rubra Vera. Ann Neurol 1980;7:81-84.

24 Crawford DC et al. Spinal Cord Compression by Extramedullary Hematopoiesis in Myelofibrosis. Postgrad Med J 1984;60:62-63.

25 Appleby A et al. Spinal Cord Compression by Extramedullary Haematopoiesis in Myelosclerosis. J Neurol Neurosurg Psych 1964;27:313.

26 Kalina P, Zaheer W, Drehobl K. Cord Compression by Extramedullary Hematopoiesis in Polycythemia Vera. AJR 1995;275:1027-1028.

27 Haran M, Ni S. Recurrent Reversible Paraplegia. Lancet 2001;357:1092.

28 Pile-Spellman J, Adelman L, Post KD. Extramedullary Hematopoiesis causing Spinal Cord Compression. Neurosurg 1981;8:728-731.

29 Stahl SM, Ellinger G, Baringer JR. Progressive Myelopathy due to Extramedullary Hematopoeisis. Neurol 1979;5:485-489. 